\title{
Local Wisdom Values in Balinese Folktales That Are Relevant to Character Education for the First Grade at Primary School
}

\author{
Relin \\ Hindu Dharma Institute, Denpasar, Bali, Indonesia \\ Rasna, I. W. \\ Ganesha University of Education, Singaraja, Bali, Indonesia \\ Binawati, W.S \\ Hindu Dharma Institute, Denpasar, Bali, Indonesia
}

\begin{abstract}
This study was aimed at finding out: 1) what folklores are suitable to be taught to the first graders at primary school and 2) what local wisdom values are there in the folklores. For this purpose, the sample was determined purposively, i.e., the first grade teachers who teach Balinese language, experts in folktales (Made Taro, DK Djareken, Buda Gautama, Suardiana and education experts. The data were collected through documents recording method, data cards and interview. The data were processed descriptive- qualitatively. The results showed that 1 ) the folktales that are suitable to be taught to the first graders at primary school are as follows: 1) folktales that teach the students to speak interact and socialize politely, education, and storytelling for 5 minutes. The local wisdom values contained in folktales are: 1) compassion (karuna); 2) Tri Hita Karana; 3) Tri Parartha; 4) Lascarya 5) alertness; 6) Kharma phala; 7) politeness; 8) Tri Dandim; 9) Mitia Hrdaya. In this context, the suggestion made is that the folktales that are suitable to be taught should meet the criteria (honesty, faith, and respect) that facilitate the teaching and learning process.
\end{abstract}

Index Terms - tale, folk, relevance, character education

\section{INTRODUCTION}

Universitas Pendidikan Ganesha (Undiksha) has Research Master Planning (RIP) with the following road map; 1) existing condition (2007-2011) 2; consolidation period (2012-2016) and development period in 2016-2020 (RIP Undiksha, 2012: 22-24). In 2015 Undiksha entered the consolidation period that consists of best researches and nonbest researches.

The research proposal entitled" Integrating local wisdom values in Balinese Folktales into Book of Balinese Lesson in Character Education for the First Graders at Primary School" which is one of the best researches in RIP Undiksha 2012. This best research entitled Educational Strategy for Values and Character with the theme Values and CharacterBased Education should accommodate science and technology developments through in their implementation. Science and technology developments are obviously needed to support various things in human life in the earth, but this can have an effect on the welfare and miserable ness of humankind. In this context, the development of science and technology has to be done in the frame of the nation's culture and character.

The frame of the nation's culture and character with the sub-theme/topic "Developing Instructional Model for the Nation's Ideological Transformation." In this context, the of actions as the real macro-pedagogic form needs to be seriously handled, such as attitude of mutual respect and appreciation, considerateness, glorifying humanity, developing peace and harmony among followers of religions, defend the truth and develop love for the country. This is important since the real macro -pedagogic form does not fall from the sky. Although the sky collapses, the dream to make people respect each other does not come suddenly but through a long developmental process which has become tradition and culture in life (Setyaningsih, 2012, p.3). Many honesty canteens went bankrupt, since an honest attitude has not developed among children (Samani and Hariyanto, 2012, p. 2). Even Kompas daily newspaper on Monday, 20th June 2011 writes "Moral Depravation Makes Us Anxious" as the headline on the first page which states:

1) During 2004-2011 The Ministry of Interior recorded 158 Heads of Regions consisting of Governors, Regions, and Mayors involved in corruption cases

2) 42 members of the Parliament were involved in corruptions in 2008-2011 period

3) 30 members of Parliament in 1999-2004 period from political parties were involved in bribery cases in Deputy of Bi Senior Governor

4) Corruption cases have occurred in a number of institutions such as Election Commission, Judicial Commission, KPPU, Directorate of General and Bank of Indonesia. 
On the other hand, a number of cases involving law rein forcers were disclosed:

1) During 2010 the Supreme Court sanctioned 107 judges, both in the form of dismissals and reprimands. In the previous year, there were 78 judges involved to 2009 in which there were 181 attorneys. Out of 288,192 were sanctioned were public prosecutors; and

2) 294 police were dismissed from POLRI with 18 officers, 272 petty officers and 4 corporals (Samani and Hariyanto, 2012, p. 4)

Even in the educational sector, we find frau such as cheating. Kompas daily newspaper, on Monday, the 20th of June 2011 reports that plagiarism is common in some universities, such as in universities in Bandung, Yogyakarta, Gorontalo and Jakarta. Even primary school children who are thought to be innocent have committed criminal acts so that have to deal with the police. German pedagogue, FW Foerster (1869-1966) focused his attention to ethic-spiritual aspect in the process of personality development. The birth of character education is the representation of Rousseau an natural pedagogy and Deweyan instrumentalist pedagogy (Meitafitrealina in http://blog.umy.ac.id). In this context, an activity that cannot be imagined to have been done by primary school children, that is, thievery was done by a primary school child a few times. The stealing of money and science teaching aids were done by the child during a school vacation in the school year 200912010.Primary school children have also been involved in violence toward their classmate, a primary school girl in a prayer room in Bukit Tinggi. A similar phenomenon was also found in Jakarta to a primary school child. He died after being treated violently by his friend. This shows that the nation's morality has undergone decadence, in which a primary school child has done something which deviates very far away from the norm of a civilized nation. Thus, a high quality character needs to be built since the critical period to form an individual character. Many scholars said that failure in building character earlier will form a problematic personality in the future (Antoro, 2012, p. 1).

Psychologists call childhood the golden age. It is called golden age because this age has turned out to determine his or her ability, around $50 \%$ of adult's intelligence had been reached at 4 years old. The next $30 \%$ occur at 8 years old (at a primary school year). And the rest $(20 \%)$ at junior secondary school age (Antoro 2012, p. 1). This shows that character education should be given in the family domain. Then, the character educational materials should be given to primary school children.

Problems of the study

Based on the explanation in the background of the study in 1.1, the problems to be studied are shown in Table 01 as follows.

TABLE 01.

STATEMENT OF PROBLEMS

\begin{tabular}{|l|l|}
\hline No. & Statement of Problems \\
\hline I. & First Year \\
1.1 & What folktales are suitable to be taught to the first grade at primary school? \\
1.2 & What local wisdom values are contained in the folktales? \\
\hline II. & Second Year \\
2.1 & What Balinese folktales are suitable to be taught to the first grade at primary \\
\hline & school according to (a) experts and , b) practitioners (teachers)? \\
\hline 2.2 & What local wisdom values are suitable to be given to the first grade primary school children according to a) experts , b) \\
& practitioners (teachers)? \\
\hline
\end{tabular}

Aims of the study

The aims to be reached within the three years period are

1) To know the folktales that are suitable to be taught at the first grade at primary school (the first year aim)

2) To know local wisdom values contained in the folktales (the first year aim)

3) To find out folktales that are suitable to be taught to the first year children according to experts and practitioners

4) To find out local wisdom values contained in Balinese folktales that are suitable to be taught to the first graders at primary school according to experts and practitioners.

The Urgence (excellence) of Study

This study is urgent because by finding the solution (in the form of model) for character education through the integration of local wisdom values in Balinese folktales that are relevant for character education at the first grade of primary school means that primary school children will obtain character education since the early years so that it will be easy to educate them.

\section{Targeted findings}

The study has the target to find local wisdom values in Balinese folktales that are relevant for character education for the first graders at primary school.

\section{Contribution of the Study Results to Knowledge}

Based on the explanation in the background, the statement of the problems, specific aims, urgency and targeted findings as explained above, then the contribution of the results of the study to knowledge is that the study will provide an effective and useful character education model through local wisdom values contained in Balinese folktales that are relevant for character education at the first grade of primary Scholl. In this way teachers of Balinese will be facilitated in looking for materials for teaching Balinese and character education. 


\section{A. Local Wisdom}

Puma mentions that local wisdom is local knowledge (Puma, 2010, p. 2). After being put into effect, Local Act No 22/ 100 makes people increasingly talk about local wisdom.. Hobsbown (1983) in Mudana (2003) defines local wisdom as a set of practices that are usually determined by regulations that are accepted clearly or unclearly and rituals or something symbolic that are meant to develop values and particular norms of behaviours through automatic repetition that implies the presence of balance and harmony in the past (Purna, 2010: 2). Local values are the ability to behave and empower the potential of local noble values. That is why local value is an entity that determines the dignity in the community (Geartz, 2007). That is why local wisdom is the truth that has become a tradition in a region (Gobyah, 2003).

Classification of Local Values

Local values are classified into 1) system of management; 2) customary values; and 3) mechanism and procedures, including use of space

\section{- System of management}

The social system of a region regulates the social structure and relations with the local community such as Dalian Natalu in North Sumatra, Nagari in West Sumatra, Kasultanan and Kasunanan in Java, and Banjar in Bali. Toraja society has an institution and social organization that manage the life in the rural environment. Every region has a custom. The customary leader in Toraja is called Bua (Buletin Tata Ruang, 2009). The custom leader has autonomy in making decisions and sanctions and social fines for the violaters of the regulations and customary laws.

\section{- Value System}

A value system is developed by the traditional community that regulates ethics to judge the good and the bad and correct and incorrect behaviours. For example in Bali there is the Tri Hita Karana value system that strengthens the community life values in relation to God, human and nature. The customary regulations have to be obeyed by the community. Whenever there is a member who violates a regulation, he or she has to accept the customary sanction.

\section{- Characteristics of Local Wisdom}

Local culture is a system or a way of life that develops and is owned by the region and is passed on from generation to generation. Local culture is made up of various elements such as religion, custom, language, agriculture, implements, clothes, architecture and art.

Characteristics of Local Wisdom

1) Able to defend itself from a foreign culture.

2) Able to accommodate a foreign culture

3) Able to integrate a foreign cultural element into the indigenous culture.

4) Able to control

5) Ability to give a direction to the cultural development

\section{- Exploring Local Culture}

The exploration of local culture is a conscious effort to maintain and protect traditional culture from economic and social attacks from the world communities that cause the environmental damage Now, people are afraid of a multidimensional crisis and an increase in the degradation of natural resources and human resources. Local knowledge which is integrated into belief system, norms, and culture which are expressed in traditions and myths that have developed from hundreds of years (from generation to generation) such as : agriculture, customary forest management and conservation of natural resources. Some characteristics that need to be met by local practices to be accepted as a local wisdom are:

1. still existing

2. in accordance with community development

3. in accordance with the principles of the unity of the nation of the republic of Indonesia which are regulated by regulations.

An example of a wise practice in relation to the environment that has been explored in an effort to conserve water resources is: 1) the belief in the presence of a supernatural beings that live in huge trees with a large canopy or in a cave. The concept underlying the prohibition of urinating under a huge tree since the area below the ground where the tree grows is a water resource is a traditional behavior that teaches the young people not to damage the nature so that the quality of water and water discharge can be maintained.

\section{- Functions of Local Wisdom}

Sirtha (2003) states that the functions of local wisdom are as follows: (1) to conserve natural resources, 2) to develop human resources, 3) to develop culture and knowledge, 4) as advice, prohibitions and beliefs.

\section{B. Character Education}

\section{- Definition of Character Education}

Character education consists of whatever positive practices of the teacher that has an effect on the students' character (Samani and Hariyanto, 2012:43). This reflects that character education is a conscious and serious effort of a teacher to teach values to the students (Winton, 2010). Character education becomes an educational movement that supports the students' social, emotional and ethical developments. Hence, character education has to be planned to facilitate the students in recognizing, taking care of and internalizing character values in an integrated manner in the process of 
teaching in all subjects, in the activity of student development at school in all affairs (Kemdiknas, 2011, p. 2). In line with this Ratna Megawangi (2004, p. 95) mentions that character education is an effort to educate children in order that they can make wise decisions and practice them in daily life, so that they can contribute positively to the environment. While Fakry Gaffar (2010, p. 1) mentions that character education is a process of life value transformation to be developed in a person so that the values become integrated in his or her behavior.

\section{- Nature of Character Education}

A good habituation is important in character education. Departing from this habit it is hoped that the students do not only understand (cognitive) which is correct, and which is incorrect, but are also able and sensitive to feel (affective) good values and are accustomed to perform good things (psychomotor) (Kemdiknas, 2011, p. 1). This means that character education is not moral knowing, but also loving good (moral feeling), and moral action. This shows that character education has a higher status than moral education (Mulyasa 2011, p. 3). Character education stresses on good habits which are practiced and performed continuously (Kemdiknas, 2011, p. 1; dan Mulyasa, 2011, p. 3).

\section{- Local Wisdom Values}

Character education through education that is inspired by local wisdom that is presented in tales is very urgent (Rasna, 2015, p. 16). In this context, then character education that is inspired by local wisdom will be presented in a book entitled Pelajaran Bahasa Bali Siswa SD Kelas I (Balinese Lesson for the First Graders at Primary School). This is done since Indonesians, especially, and other eastern peoples in general evaluate our characters and behaviors as those which are polite and those which are not (Efendi, 1982, p. 5). Aware of this it seems that the effort toward the reinforcement of moral values and spiritual values through education that is inspired by character in the students and adolescent's life becomes very vital (Nashir in Suara Karya, the 1 th of Oktober 1993). On this ground, all forms of education that are inspired by character education should start from early ages, when the children start to be able to understand That is why local wisdom values in the folktales integrated into a Balinese book for the first graders at primary school, such as the folktale entitled Tunjung Mas (Gold Liiy)that contains local wisdoms such as a) Karuna (compassion), b) Tri Hita Karana, especially a harmonious life between human and God (religious), and c) Tri Parartha (punya, asih, and bhakti); a folktale entitled Lipi Selem Bukit ( Black Snake on the Hill) with local wisdom values as such as a) human-nature harmonious relation and lascarya. A folktale entitled Siap Badeng ( Black Hen) with local wisdom values of a) alertness, andkarmapala. A folktale entitled Ayam Putih Bertelur Emas (White Hen Laying Gold Eggs) with the local wisdom values of a) Tri Dandim (three elements fo control: namacika (mind), wacika (speech), and kayika (act) and b) Mithia Hrdaya (avoiding being prejudiced) (Rasna, 2015, pp. 39-48).

\section{- Character Values}

The major characters selected are: 1) attitude in relation to Godand 2) attitude in relation to oneself, 3) attitude one's family, 4) attitude in relation to the society and nation, and 5) attitude in relation to the surroundings (Samani dan Hariyanto, 20 12, pp. 46- 49 and Asmani, 2011, pp. 36-41). Lickona (1992) differentiates two types of values: 1) moral values such as honesty, responsibility, impartiality, responsibility to keep promises, to pay debts and to love children.2) nonmoral values. We are bound by moral values, even when we do not like them. But nonmoral values do not have such an obligation. Nonmoral value expresses what we want. I personally am able to respect activities like listening to classical music's, reading good novels, and using Facebook. But, it is obvious that there is no obligation to do them (Kesuma et al, 2011, pp. 63). In brief, these can be shown in Table 03 as follows.

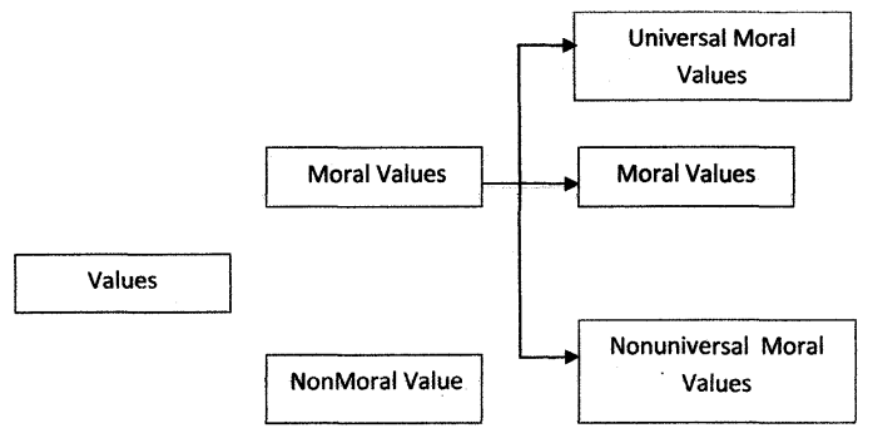

Moral categories according Lickona in Kesuma et al., (2011: 65)

\section{METHOD}

\section{A. Study Design and Methods}

\section{1) Study Design}

Based on the problems and aims of this study, the design that was used was descriptive research design. This design was used as the grand design within the period of 3 years (2016-2018). The stages are described in Table 05 as follows. 
TABLE 04.

Flow-CHART OF THE STUdy ENTITLE LOCAL WISDOM IN BALINESE FOLKTALES RELEVANT FOR CHARACTER EDUCATION FOR FIRST GRADERS AT PRIMARY SCHOOL.

\begin{tabular}{|c|c|}
\hline First Year (2016) & Second Year (2017). \\
\hline $\begin{array}{l}\text { First year Analysis of Needs } \\
\text { - Data about folktales relevant for the first graders at primary } \\
\text { school } \\
\text { - Local wisdom values that exist in the folktales }\end{array}$ & $\begin{array}{l}\text { Development process that consists of: } \\
\text { - Analysis of local wisdom values in the folktales from cognitive, } \\
\text { affective and psychomotor aspects } \\
\text { - Improvement through expert judgment and a test by practitioners. }\end{array}$ \\
\hline $\begin{array}{l}\text { Study Outcomes } \\
\text { - Research Report } \\
\text { - Article }\end{array}$ & $\begin{array}{l}\text { Study Outcomes } \\
\text { - Research Report } \\
\text { - Article }\end{array}$ \\
\hline
\end{tabular}

Details of the stages of research with stages during 2 years as follows.

\section{a) First Year}

\section{Initial Stage}

The data needed for the first year are as shown in Table 05, this study used informal approach, that contains spontaneity element and has the pattern (because of the existence of guidance).

2. At the time when the study was in Progress in Relation to Achievement that is related to the Teacher

- This approach was aimed at finding data to explore the data on folktales that are suitable for the first graders at primary school. The teachers were selected and priority was given to first grade teachers or those who have experienced teaching, even having experience in teaching the first grade.

- Education that is related to the student

This approach contains an analysis of first condition of the students by using Bloom's taxonomies (cognitive, affective and psychomotor). In addition, there is also an analysis of children's opinions about films that use tales preferred by children. This information is important to explore data about what factors behind their preference. When these data can be obtained it is hoped that they can be applied into the folktales.

\section{b) Second Stage}

The second year study about the analysis of Balinese folktales that are relevant in terms of affective, cognitive and psychomotor aspects are to be continued with expert judgment and practitioner (teacher) judgment through desk evaluation. The results from expert judgment are intended for formulating Balinese folktales and their values that are relevant for the first grades at primary school. The results of desk evaluation by the first graders will be useful as the instrument to verify the validity of the Balinese follctales.

\section{B. Population and Sample}

The population is differentiated into a) the population of first grade teachers at primary schools who teach Balinese b) the population of educational experts, especially those who understand Balinese and folktales c) the population of folktales and d) folktale experts.

The selection of the population of the first grade teachers at primary schoolss as key informants was done purposively based on expertise, experience, and credibility. Since folktale experts are scarce, then the experts were directly used as the sample, they were Made Taro for Badung, Wayan Buda Gautama for Gianyar, Dewa Ketut Djareken for Buleleng, and Dr. Wayan Suardiana for Denpasar City. The sample was determined purposively. Purposive sampling was also used for selecting teachers and folktales. The first year study (2016) used the sample of teachers as shown in Table 05.

TABLE 05.

DisTRIBUTION OF THE NUMBERS OF SAMPLE FOR THE FIRST YEAR STUDY (2016)

\begin{tabular}{|l|l|l|l|}
\hline \hline No & Regency / City & Number of Primary Schools & Number of Teachers \\
\hline 1. & Buleleng & 4 & 4 \\
\hline 2. & Badung & 4 & 4 \\
\hline 3. & Denpasar City & 4 & 4 \\
\hline 4. & Klungkung & 4 & 4 \\
\hline 5. & Tabanan & 4 & 4 \\
\hline Total & $\mathbf{2 0}$ & $\mathbf{2 0}$ \\
\hline
\end{tabular}

Distribution of the Numbers of Sample for the Second (2017) was the same as that for the First Year Study (2016).

\section{Method for Collecting Data}

The data collected and methods for collecting data are as shown in Table 06 as follows. 


\begin{tabular}{|c|c|c|c|c|c|}
\hline Year & Statement of Problems & $\begin{array}{l}\text { Method for } \\
\text { Collecting } \\
\text { Data }\end{array}$ & Instruments & $\begin{array}{l}\text { Data } \\
\text { Analysis }\end{array}$ & Outcomes \\
\hline $\mathrm{I} / 1$ & $\begin{array}{l}\text { What folktales are suitable } \\
\text { to .be taught to the first } \\
\text { graders at } \\
\text { primary school. }\end{array}$ & Document recording & Data cards & $\begin{array}{l}\text { Descriptive - } \\
\text { qualitative Method }\end{array}$ & $\begin{array}{l}\text { 1. Research report } \\
\text { 2. Article }\end{array}$ \\
\hline 2. & $\begin{array}{l}\text { What local wisdom values } \\
\text { are contained in the } \\
\text { folktales? }\end{array}$ & Document recording & Data cards & & \\
\hline $\mathrm{II} / 3$ & $\begin{array}{l}\text { What Balinese folktales to } \\
\text { be 4ught to the first graders } \\
\text { at primary school? } \\
\text { According to (a) experts, (b) } \\
\text { practitioners (teachers) }\end{array}$ & $\begin{array}{l}\text { Text analysis, } \\
\text { interview }\end{array}$ & $\begin{array}{l}\text { Balinese folktales } \\
\text { and Interview guide }\end{array}$ & & $\begin{array}{l}\text { 1. Research report } \\
\text { 2. Article }\end{array}$ \\
\hline 4. & $\begin{array}{l}\text { What wisdoms are suitable } \\
\text { to be taught to the first } \\
\text { graders at primary school } \\
\text { according to (a) experts, (b) } \\
\text { practitioners (teachers). }\end{array}$ & $\begin{array}{l}\text { Interview } \\
\text { and direct recording }\end{array}$ & $\begin{array}{l}\text { Interview } \\
\text { guide, paper and pen }\end{array}$ & $\begin{array}{l}\text { Descriptive - } \\
\text { qualitative } \\
\text { method }\end{array}$ & \\
\hline 5. & $\begin{array}{l}\text { How do students respond } \\
\text { academically and no } \\
\text { academically? }\end{array}$ & $\begin{array}{l}\text { Observation, } \\
\text { interview, direct } \\
\text { recording }\end{array}$ & $\begin{array}{l}\text { Observation } \\
\text { guide, interview } \\
\text { guide, paper, pen }\end{array}$ & $\begin{array}{l}\text { Descriptive- } \\
\text { qualitative } \\
\text { method }\end{array}$ & \\
\hline
\end{tabular}

\section{Technique for Analyzing Data}

In line with the type of approach and the characteristics of this study, the technique for analyzing data used in this study was descriptive-qualitative technique from the beginning to the end. The stages of analysis started by arranging data collected, categorization, patterning based on the concepts of local until the conclusion could be drawn.

\section{RESULTS AND DISCUSSION}

\section{A. Folktales That Are Suitable to be Taught to the First Graders at Primary School}

Folktales that are suitable to be taught to the first graders at primary school according to teachers, folktale experts, and education experts.

\section{1) The Teachers' Opinion}

First grade teachers at primary school who have direct experience in the field said that the material from folktales that are suitable to be taught to the first grade at primary school are those that are adapted according to:

a) Child cognitive development

b) Child language development

c) Child socio-culture (ethno-pedagogy)

d) Child natural environment and learning environment (eco-pedagogy)

Child cognitive development should be considered because existing folktales are seen more from the writer's value perspective, without considering who the consumers are. Especially, when the consumers are the first graders of primary school whose needs in learning development have to be considered. Learning will take place as the effect of their active participation in learning from the people close to them including teachers and parents. The first graders of primary schools according to Piaget are in the concrete preoperational stage that focuses on direct experience, while folktales do not consider for whom they are written. Thus, the folktales that will be used as learning materials have to be modified before being used as learning materials both in terms of vocabulary, sentence structure, cognitive development, the match between the time needed for reading them and the time available in the teaching and learning process to facilitate children to learn something from them. Children are fond of recognizing and identifying objects in their environment, thus the teacher also needs to facilitate children well in learning by giving simple directions.

\section{2) The Folktale Experts' Opinion}

According to folktale experts, like Made Taro, W. Buda Gautama and Wayan Suardiana, the folktales need to be adjusted first before being used as learning materials. It means that if the folktale will be used as learning material, before it is used it has to be modified to suit the development of the children who will be taught in terms of cognitive developmental psychology, language development and relevant values to be taught to the students. This relevance will contribute to the level of the students' understanding. The level of the students' understanding is facilitated by: a) the children's cognitive development, b) their language development, c) their sociocultural environment; and d) their natural environment. In addition, the identification of the folktales is also meant to adjust the material to the time available. For example, telling a story for 5 (five) minutes like what is presented by Made Taro in Bali Post daily newspaper every Sunday. Since the folktale was written in the past, with the condition that is very different from a current story condition, then the teacher needs to try to present the story so that 1) the children are interested in the folktales as they are interested in child stories on TV such as Doraemon, 2) the whole story presented without modification, for example, will be long, especially in a language that does not suit the children's age, thus the story will 
be left by the children, 3) considering this condition, it is better if the modification is completed with information technological presentation format, and in a simple language that suits the children's age.

\section{3) The Education Experts' Opinion}

According to the opinion given by the education experts, folktales are less liked by children. Children prefer child stories in films on TV to folktales. After this phenomenon was analyzed, it turns out that there are some causes why folktales are left by the children. The causes are: 1) internal factors and 2) external factors. The internal factors come from the folktales themselves such as settings, in which folktales have the settings in the mountain and in the jungle that are less suitable than the contemporary child's natural environment, in addition to their less suitability in terms of child developmental psychology. Folktales use characters from shadow play gods, with reference to their supernatural powers which is not suitable! less matched with the level of the children's cognitive ability. Since children are at the concrete preoperational stage, while the material is at abstract cognitive stage. This causes disconnection between the material and the children's cognitive ability. This also contributes to the reason why folktales are left by the children. 3). The language used in folktales tend not to fit the first grader's language. That is why they have to be modified to suit the needs. The external factors that contribute to the reasons why the folktales are left by the children are: 1) the difficulty to find story tellers. It is different from the situation in the past .Grandfathers and grandmothers around 1960s always or at lest often told stories first before their grandchildren went to bed. Now this is difficult to find this practice. in place of this, parents buy electronic gadgets for their children in order they can focus on their jobs to make money. The second external factor is IT. The presentation in children's stories is far more interesting than that in folktales which do not use IT. To make children like folktales the presentation has to be adjusted to today's development, both in relation to the internal and the external factors. Based on the explanation above, it can be ascertained that the folktales that are suitable to be taught to the first graders at primary school have the characteristics: 1) suitable with the cognitive development, 2) suitable with children's language development, 3) suitable with the children's sociocultural and natural as well as learning environments. The existing folktales still need to be modified before being used as learning materials.

\section{B. Local Wisdom Values That Are Found in Balinese Folktales}

Discipline and diligence in the story entitled Cerita Cupak Gerantang (The Story of Cupak Gerantang). Cerita Cupak Gerantang contains discipline and diligence values because early in the morning, I Grantang carries a plowing implement while driving his cow to plow in the rice field. Beside discipline value, politeness value is also present in this folktale. This is shown when I Grantang is slandered by 1 Cupak by saying that I Grantang only plays and I Cupak works hard plowing the rice field. This makes I Grantang tortured and expelled by his mother. He faces this politely, full of good deeds and accepts what he gets. The story entitled Laran I Balian Sakti (Petaka Ilmu Si Dukun Sakti) (The Predicament of a Shaman's Occult Science) contains the lesson that the application of science should be for public welfare. It is not allowed to get knowledge by stealing and cheating. Knowledge has to be applied correctly. The misapplication does not only give a bad impact to other people, but it also gives a bad impact to oneself.

1) Educational value in Tuwung Kuning (Yellow Eggplant)

The story I Tuwung Kuning has an educational value that teaches people not to gamble. The reason is that gambling does not only cause material loss but it also causes quarrelling in the family and even it can cause death.

2) Compassion value with politeness in the folklore entitled Cerita Rakyat Tunjung Mas (The Story of Gold Lily) Tunjung Mas contains the local wisdom of compassion (karuna), which is found in polite utterances Politeness is a refined characteristic from the points of view of grammar and behavior toward all people (Mustari, 2014: 129).

3) Religious value in Cerita Tunjung Mas

The religious value is seen in Pucang's behavior who gets down slowly into a pond while praying. The religious value is the character value in relation to God according to the teaching of the religion (Mustari, 2014: 1).

4) Kindness and compassion as part of Tri Parartha in Cerita Tunjung Mas Pincang's behavior in this story is based on the concept of character education of willingness to help. The willingness to help is an attitude and action of always trying to help other people (Mustari, 2014: 183)

5) Lascarya (sincenty) and the harmony between human and nature in Cerita Lelipi Selem Bukit

The value of lascarya (sincerity) is found in Cerita Lelipi Selem Bukit in the form of 1 Tundeng's sincerity in which he is willing to sacrifice himself by becoming a snake (a human who has taken the appearance of a snake) to dedicate himself to I Jero Pasek to keep his field.

6) Karma phala value in Cerita Siap Badeng (Black Hen)

The karma phala value in this story is seen when Men Kuuk plans to kill Siap Selem and her chicks who are staying at her house. This act on the contrary to her wish makes her miserable since she attacked a stone wall used by the hen to protect her chicks. Men Kuuk attacked a wrong target because her foot slipped.

7) Tri Dandim (Three Elements in Self Control)

\section{CONCLUSION AND SUGGESTION}

\section{A. Conclusion}


1. The folktales which are suitable to be taught to the first graders at primary school have the following characteristics: 1) they teach a) politeness in speaking, interactions, behaviors, and education; b) strong religious faith and c) honesty 2) the language in the folktales is simple; 3) the stories are short, like telling a story in 5 minutes, but keeps on focusing on the characters of religious faith, honesty, and mutual respect; 4) the contents suit 's the students' cognitive development so that the do not go beyond the limit of the first grader's ability.

2. The local wisdom values that are contained in the folktales are 1) karuna (compassion); 2) Tri Hita Karana 3) Tri Parartha 4) Lascarya (sincerity); 5) alertness; 6) karma phala; 7) politeness; 8) Tri Dandim (three elements in self control ); 9) never being preju4iced (Mithia Hrdaya)

\section{B. Suggestion}

Based on the conclusion above, it is suggested that in character education for the first graders at primary school the folktales are not used wholly, but being modified according to the time available, readiness, children's age and children's cognitive development. The character education that is relevant to the first graders at primary school starts from the values of religious faith, honesty, and mutual respect and these values have to be emphasized in every level by giving examples of life experience disclosure.

\section{REFERENCES}

[1] Ahmad, Zakaria (ed). (1985). Military Civilization Relations in South East Asia. Singapore: Oxford University Press.

[2] Asmani, Jamal Ma'mur. (2011). Buku Panduan Internalisasi Pendidikan Karakter di Sekolah. Jogyakarta: Diva Press.

[3] Antoro, Dwi. (2012). Pendidikan karakter di sekolah dasar. Retrieved on http: atariuz.blongspot.com. Accessed on 10 February 2014.

[4] Bali Post. (2013). Hilangnya keakraban guru-murid di Bali.Monday, $8^{\text {th }}$ April 2013. p.3.

[5] Choesin, Ezra. M. (2002). Connectionsn. Alternatif dalam Memahami Dinamika Pengetahuan Lokal dalam Globalisasi. "dalam Antropologi Indonesia. Fakultas limu dan Ilmu Politik UI: Yayasan Obor Indonesia.

[6] Effendi, Samsoeri. (1982). Etiket Sopan Santun Pergaulan Menurut Tata Krama Nasional. Surabaya: Karya Anda.

[7] Forrester, M. A. (1996). Psychology of Language: A Critical Introduction. London: Sage Publication.

[8] Geertz Clifford. (2000). Negara Teater. Penerjemah : Hartono Hadikusumo Yogyakarta : CV. Adipura.

[9] Kusuma Dharma, Triatna, and Permana. (2011). Pendidikan Karakter. Bandung: PT Remaja Rosdakarya.

[10] Lickona, Thomas Terjemahan Suma Abdi Wamango \& Jean Antunes Rudolfzien. (2012). Character Matters Persoalan Karakter Bagaimana Membantu Anak Mengembangkan Penilaian yang Baik, Integritas, dan Kebijakan Penting Lainnya. Jakarta: PT Bumi Aksara.

[11] Mudana, Gde. (2003). "Kearifan Lokal dan Wacana ke Praksis; (Artikel path Harian Bali Post 11 September.

[12] Mulyasa, H. E. (2011). Managemen Pendidikan Karakter. Jakarta: PT Bumi Aksara.

[13] Megawangi, Ratna. (2004). Pendidikan Karakter Solusi yang Tepat untuk Membangun Bangsa. Jakarta: BP Migas.

[14] Nashir, Haedar. (2013). Pendidikan Karakter Berbasis Agama dan Buda. Yogyakarta: Multi Presindo.

[15] Puma, I Made. (2009). Penguatan Budaya Lokal Melalui Industri Kreatjf untuk Kesejahteraan Masyarakat dalam Jnana Budaya. Edisi 14 No. 14/Vllh/2009. Denpasar.

[16] Rasna, I Wayan. (2015). Peranan Kearifan Lokal Cerita Rakyat Bali dalam Pendidikan Karakter Siswa SD: Sebuah Kajian Etnopedagogi. Laporan Penelitian Puslit Bahasa Seni, dan Budaya FBS Undiksha.

[17] Samani, Muchlas dan Hariyanto. (2012). Konsep dan Model Pendidikan Karakter. Bandung: Remaja Rosdakarya.

[18] Setyaningsih, Anjar. (2012). Pembelajaran Sastra Tradisional di Sekolah Guna Membangun Kecintaan terhadap Kebudayaan Indonesia dalam Prosiding Konfrensi Internasional Kesusastraan XXII UNY-HISKI Buku 4 Sastra Anak dan Kesadaran Fiminis dalam Sastra. Yogyakarta: FBS UNY.

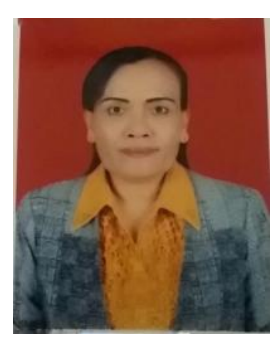

Relin D.E. M.Ag has obtained her doctorate degree in Udayana University in 2011. She was born in Banyuwangi on the 1st August 1968. She is the lecturer of Hindu Dharma Institute in Denpasar. Her interests of study are Philosophy, education, and culture. She had published several articles either in local or international journals. In 2014, she had published her articles entitled "The philosophy of Java script in cycle of life of Javanese community in modern era Discovery The International Daily. In 2015, she had published Hyper Spirituality Of Puppet In The Jawa Society In Modern Era and Philosophy of Cremation in Bali. Her recent study has been published entitled Marriage philosophy of Balinese culture 


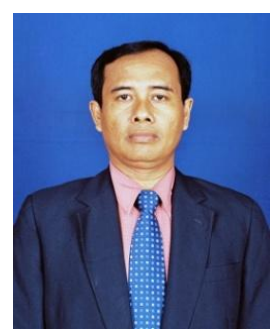

I Wayan Rasna, M. Pd. Has persued his doctorate degree in Udayana University in 2010. He is a professor in Bahasa Indonesia Department in Language and Art Faculty, Ganesha University of Education. His research interests include Linguistics, Socio-ethno psycholinguistics, sociosemantics-echolinguistics, and so on. He has published several articles either in local or international journals. His study in 2010 has been published in EJournal of Linguistics Program Pascasarjana Universitas Udayana entitled Ajiblegodawa Text in the Perspective of Functional Systemic Linguistics. His recent study has been published in journal of education and social sciences in 2016 entitled A Strategy to Preserve Traditional Medicine Plant (TMP) Lexical Icons in Usadha Implementation As Balinese Local Genius by Dukuns (Traditional Healers).

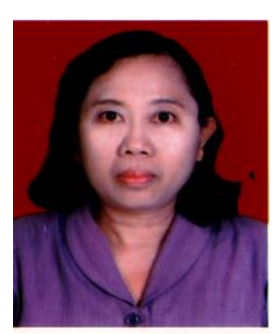

Ni Wayan Sariani Binawati, M.Ag is the lecturer of Hindu Dharma Institute in Denpasar, Bali. She was born in Denpasar $23^{\text {th }}$ of February 1964. Her research interests includes education, language and literature, and Hindu literature. She had written several international and local paper. Her study in 2015 was published in Proceeding International Seminar on Religious Manuscripts in Multiculturalism for a Better Life (Humanity and Peace) entitled Etno Pedagogic Value in The Lontar of Sang Hyang Aji Saraswati. She also has published international paper entitled Teachers Function as A Model in Character Education in 2016. 